\title{
Venous Occlusion after Transvenous Pacemaker Implantation-Is There a Role for New Oral Anticoagulants?
}

\author{
Giuseppe Mario Calvagna $\cdot$ Salvatore Patanè
}

Published online: 2 December 2014

(C) Springer Science+Business Media New York 2014

The use of new oral anticoagulants (NOACs) in numerous scenarios may be very interesting although their use always requires thorough evaluation regarding risks and benefits based on an in-depth understanding of each patient's comorbidities. Their perioperative use also requires further study [1-5]. We would like to focus the attention on a possible interesting use of NOACs. Central venous occlusions in pacing patients are often asymptomatic $[6,7]$ due to the development of an adequate venous collateral circulation, but they can cause more difficulties in patients needing a device revision/upgrade/extraction requiring advanced tools and more time $[6,8]$. So far several pacing venous occlusions have been described, including superior vena cava (SVC) occlusion [9-11], subclavian vein occlusion $[12,13]$, axillary vein occlusion [14], inferior vena cava (IVC) occlusion [15], subtotal innominate vein occlusion [16], and internal jugular vein occlusion [17]. Moreover permanent pacemaker-related upper extremity deep vein thrombosis has been found [18] with risk factors such as diabetes, most frequently, followed by smoking, hypertension, obesity with a body mass index $\geq 30$, history of acute myocardial infarction, chronic obstructive pulmonary disease and history of congestive cardiac failure (15\%) and responding to anticoagulation therapy while antiplatelets were not found protective [18]. Also, atrial fibrillation, foreign body-type reaction, and hypercoagulability have been suggested as possible mechanisms of pacing venous thrombosis [19]. Notably, implantable cardioverter defibrillators leads, after a long dwell-time, have been found

G. M. Calvagna $(\bowtie) \cdot S$. Patanè

Cardiologia Ospedale San Vincenzo-Taormina (Me) Azienda

Sanitaria Provinciale di Messina, Contrada Sirina, 98039,

Taormina, Messina, Italy

e-mail: gicalvagna@tiscali.it affected by fibrous adherences uniformly distributed along the lead course and careful lead selection is recommended at the time of implantation to prevent adherences [20]. We usually search to remove the preexisting electrodes with a percutaneous approach, but if the adhesions between the leads and the venous wall cannot be gone over, in our opinion the surgical strategy is often mandatory [21-23]. Nowadays prevention of pacing venous occlusions represents an increasingly serious challenge as well its optimal management. Furthermore, perioperative lead extraction management varies between extraction centers, and no clinical guidelines [24] have focused on the need for anticoagulation. Nevertheless, routine peri- and postoperative anticoagulation has been advocated as a means to prevent vein occlusions including pulmonary embolism $[25,26]$. We think that NOACs may find a possible application in this emerging clinical scenario. Additional researches are needed and the journey of NOACs could be longer than expected.

Acknowledgments Author contributions: Giuseppe Mario Calvagna prepared the references; Salvatore Patanè wrote the work.

Conflict of Interest None.

\section{References}

1. Madan S, Shah S, Partovi S, Parikh SA. Use of novel oral anticoagulant agents in atrial fibrillation: current evidence and future perspective. Cardiovasc Diagn Ther. 2014;4(4):314-23. doi:10.3978/j.issn. 2223-3652.2014.08.01.

2. Kaski JC. New challenges ahead for the newer oral thrombin inhibitors that aim at replacing warfarin in clinical practice-any role for scientific societies in the debate? Cardiovasc Drugs Ther. 2012;26(4): 359-60. doi:10.1007/s10557-012-6393-1. 
3. Jalota A, Scarabelli TM, Saravolatz L, Bakhsh MU, Agrawal P, Jalota $R$, et al. Novel anticoagulants for stroke prevention in patients with atrial fibrillation. Cardiovasc Drugs Ther. 2014;28(3):247-62. doi: 10.1007/s10557-014-6524-y.

4. Kwong JS, Lam YY, Yan BP, Yu CM. Bleeding of new oral anticoagulants for stroke prevention in atrial fibrillation: a meta-analysis of randomized controlled trials. Cardiovasc Drugs Ther. 2013;27(1):2335. doi:10.1007/s10557-012-6426-9.

5. Strobeck JE. Stroke prevention in atrial fibrillation: managing the risks in light of new oral anticoagulants. Cardiovasc Drugs Ther. 2012;26(4):331-8. doi:10.1007/s10557-012-6396-y.

6. Kutarski A, Pietura R, Młynarczyk K, Małecka B, Głowniak A. Pacemaker lead extraction and recapture of venous access: technical problems arising from extensive venous obstruction. Cardiol J. 2012;19(5):513-7.

7. Sohal M, Williams S, Akhtar M, Shah A, Chen Z, Wright M, et al. Laser lead extraction to facilitate cardiac implantable electronic device upgrade and revision in the presence of central venous obstruction. Europace. 2014;16(1):81-7. doi:10.1093/europace/eut163.

8. Li X, Ze F, Wang L, Li D, Duan J, Guo F, et al. Prevalence of venous occlusion in patients referred for lead extraction: implications for tool selection. Europace. 2014.

9. Ceresa F, Sansone F, Patanè S, Calvagna GM, Patanè F. Superior vena cava obstruction as late complication of biventricular pacemaker implantation: Surgical replacement of the malfunctioning previous leads. Int J Cardiol. 2014;176(3):e83-5. doi:10.1016/j.ijcard.2014.07.164.

10. Gebreyes AT, Pant HN, Williams DM, Kuehl SP. Be aware of wires in the veins: a case of superior vena cava syndrome in a patient with permanent pacemaker. J Community Hosp Intern Med Perspect. 2012;2(3). doi:10.3402/jchimp.v2i3.19159.

11. Rossi A, Baravelli M, Cattaneo P, Romano M, Mariscalco G, Imperiale $\mathrm{D}$, et al. Acute superior vena cava syndrome after insertion of implantable cardioverter defibrillator. J Interv Card Electrophysiol. 2008;23(3):247-9.

12. Kurisu S, Inoue I, Kawagoe T. Occlusion of the subclavian vein after pacemaker implantation. Intern Med. 2008;47(13):1279.

13. Vyselaar JR, Michael KA, Nolan RL, Baranchuk A. Left subclavian vein occlusion after pacemaker insertion. Cardiovasc J Afr. 2008;19(3):155.

14. Breuls NP, Res JC. Acute subclavian or axillary vein occlusion during biventricular pacemaker implantation. Pacing Clin Electrophysiol. 2006;29(10):1170-3.

15. Schroeter T, Dähnert I, Doll N, Mohr FW, Borger MA. Pacemakerassociated thrombotic occlusion of the inferior vena cava causing liver failure. Thorac Cardiovasc Surg. 2010;58(7):431-3. doi:10. 1055/s-0030-1249803.

16. Van Putte BP, Bakker PF. Subtotal innominate vein occlusion after unsuccessful pacemaker implantation for resynchronization therapy. Pacing Clin Electrophysiol. 2004;27(11):1574-5.

17. Fitzgerald SP, Leckie WJ. Thrombosis complicating transvenous pacemaker lead presenting as contralateral internal jugular vein occlusion. Am Heart J. 1985;109(3 Pt 1):593-5.

18. Mandal S, Pande A, Mandal D, Kumar A, Sarkar A, Kahali D, et al. Permanent pacemaker-related upper extremity deep vein thrombosis: a series of 20 cases. Pacing Clin Electrophysiol. 2012;35(10):1194-8. doi:10.1111/j.1540-8159.2012.03467.x.

19. Ayhan SS, Oztürk S, Ozlü MF, Düzenli S. Recurrent pacemaker lead thrombosis in a patient with gene polymorphism: a rare case treated with thrombolytic therapy. Turk Kardiyol Dern Ars. 2013;41(1):64 7. doi:10.5543/tkda.2013.03266.

20. Segreti L, Di Cori A, Soldati E, Zucchelli G, Viani S, Paperini L, et al. Major predictors of fibrous adherences in transvenous implantable cardioverter-defibrillator lead extraction. Heart Rhythm. 2014. doi: 10.1016/j.hrthm.2014.08.011.

21. Calvagna GM, Patanè S. Severe Staphylococcal Sepsis in patient with permanent pacemaker. Int J Cardiol. 2014;172(3):e498-501. doi:10.1016/j.ijcard.2014. 01. 048.

22. Calvagna GM, Patanè S. Intravascular recovery of electrode fragments as a possible complication of transvenous removal intervention. Int J Cardiol. 2014. doi:10.1016/j.ijcard.2014.08.115.

23. Calvagna GM, Patanè S. Transvenous pacemaker lead extraction in infective endocarditis. Int J Cardiol. 2014;176(2):511-3. doi:10. 1016/j.ijcard. 2014. 07.049.

24. Wilkoff BL, Love CJ, Byrd CL, Bongiorni MG, Carrillo RG, Crossley 3rd GH, et al. Transvenous lead extraction: Heart Rhythm Society expert consensus on facilities, training, indications, and patient management: this document was endorsed by the American Heart Association (AHA). Heart Rhythm. 2009;6:1085e104.

25. Hanninen M, Cassagneau R, Manlucu J, Yee R. Extensive thrombosis following lead extraction: further justification for routine post-operative anticoagulation. Indian Pacing Electrophysiol J. 2014;14(3):150-1.

26. Zacà V, Marcucci R, Parodi G, Limbruno U, Notarstefano P, Pieragnoli $\mathrm{P}$, et al. Management of antithrombotic therapy in patients undergoing implantation or replacement of cardiac implantable electronic devices. G Ital Cardiol (Rome). 2014;15(1):56-72. doi:10. $1714 / 1394.15520$. 